\title{
College English Teaching in China: Challenges \\ and Recommendations
}

\author{
GUO Rong \\ China University of Mining and Technology, Beijing, China
}

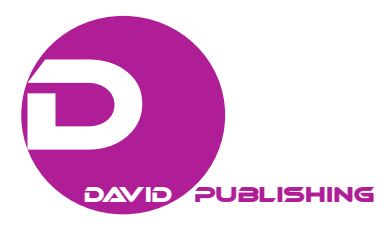

College English is a required subject for almost all non-English majors studying at tertiary level educational institutions in China, so it is deemed to be an important component for the higher education curricula. However, due to various reasons, many teachers of this subject face the challenges of getting their students motivated, or obtaining satisfactory learning outcomes. Three topics, namely motivation, Computer-Assisted Language Learning (CALL), and action research were chosen as the most relevent for the scope of this paper. Based on a review of literature and the authors' experiences and observations, this paper intends to not only address issues that deserve attention of researchers and practitioners in the domain of college English teaching in China, but also provide some recommendations that can hopefully help colleagues in this field to get inspiration for their teaching and research.

Keywords: College English, computer-assisted language learning (CALL), challenges, motivation, action research

\section{Introduction}

Most students in China study English for more than 10 years before they start their post-secondary education, where they take College English as a required course for a number of years to pass Band 4 and/or Band 6 test before they graduate with a degree. That is to say, students invest a lot of time and energy in English language learning no matter what their program of study is. Many teachers of College English have a Master's or higher degree in English language and literature, applied linguistics, or a relevant discipline, which at least theoretically indicates that they have the proper credentials to teach this required course. However, according to the authors' experiences communicating with colleagues who teach College English, and observations of College English classrooms, there are a number of challenges they face, especially student motivation, teaching efficiency, and student learning outcomes.

A review of literature on teaching English as a second or foreign language indicates that, in order to create an environment that can efficiently and effectively foster student learning in College English classroom, there are many things for teachers to consider that may enhance their regular teaching practice. This paper focuses on three topics, motivation, computer-assisted language learning (CALL), and action research.

GUO Rong, lecturer, Ph.D., School of Humanities and Law, China University of Mining and Technology, Beijing. Zuochen ZHANG, associate professor, Ph.D., Faculty of Education and Academic Development, University of Windsor. 


\section{Motivation}

Two types of motivations are often mentioned in literature on second language learning: integrative and instrumental. Integrative motivation reflects "a high level of drive on the part of the individual to acquire the language of a valued second-language community in order to facilitate communication with that group" (Gardner, Smythe, Clément, \& Gliksman, 1976, p. 199), while instrumental motivation lies in the situation where the learner's interest in learning the foreign language is associated with the pragmatic, utilitarian benefits of language proficiency, such as a better job or a higher salary. Gardner and MacIntyre’s (1991) study demonstrates that both integrative motivation and instrumental motivation facilitated learning.

According to Oxford and Shearin (1994), teachers are often unaware of their students' specific motivations for L2 language learning as students' motivations for learning a new language are individualistic and multifaceted, so teachers need to know what these motivations are and how to build on them by using a simple questionnaire or assigning an essay at the beginning of the term to obtain valuable information on student motivation. Dörnyei (1994) argued that there are many reasons for people to learn a language, so teachers should take measures to enrich student learning experience by encouraging students to set attainable subgoals, and increasing the attractiveness of course content. Tasks that involve variety and diversity are more likely to facilitate an interest in learning and a mastery or orientation (e.g., Rosenholtz \& Simpson, 1984). It is believed that students are more likely to approach and engage in learning activities when they find meaningful reasons for doing this; that is, students are more motivated to learn when they see personal relevance and meaningfulness of the content (Brophy, 1987; Meece, 1991).

English is taught as a foreign language, not a second language, in China, but research on second language teaching and learning can to a great extent be applied in foreign language teaching and learning. College English is a required course for almost all non-English majors in the tertiary education setting in China, and the vast majority of students take College English to pass Band 4 and/or Band 6 test that is required for their graduation, so their motivation is likely instrumental and specific. Iyengar and Lepper (1999) and Littlewood (1999) suggested that motivational processes may vary in different sociocultural contexts, so teachers of College English should do research on their students' sociocultural backgrounds and design learning environments that can better motivate their language learning.

Students who take College English course are from a variety of disciplines and they may not find the materials from the textbooks relevant to their field. The Internet provides an easy and fast access to the use of current and authentic materials in the target language, which is motivating for the language learner. The authentic materials available online such as online newspapers, audio and video files can help them to access current and real-time materials. Online synchronous and asynchronous communication tools such as chat room and discussion forums can also motivate language learners by providing them tools with which they can practice not only the written use of the language, but also speaking and pronunciation.

\section{Computer-Assisted Language Learning (CALL)}

CALL, a term that is used more widely than some similar terms, such as Computer-enhanced language learning (CELL), Technology-enhanced language learning (TELL), Technology-assisted language learning (TALL), Computer-assisted language instruction (CALI), Information and Communication Technologies (ICT), 
etc. (Hubbard, 2014), is playing an increasingly important role in the field of foreign language teaching with the rapid development of ICT in recent years. With the help of ICT, real-life situations can be simulated so as to help learners to have control over the learning process (O’Leary, 1998), and by using computers for free voluntary surfing, students are encouraged to wander through the Internet and read what interests them (Krashen, 2007), which may result in higher levels of literacy. CALL provides new opportunities for learners to engage in active communication that facilitates the development of second language competence (Peterson, 2005), and multimedia resources and Internet-based tools may contribute to English as a Foreign Language (EFL) students' cross cultural competence (Kim, 2005).

CALL can enable learners to work at their own pace (Hoven, 1999), but collaborative learning experience that is made available by CALL attracts more attention. According to the developmental theory of Vygotsky (1978), when learners are actively assisted in dialogic events on topics of mutual interest and value, individual and conceptual development occurs, which means that CALL can enable learners to pool their knowledge in effective ways. The extensive use of web 2.0 components, especially social networking sites (also called "social software”, “social networking sites”, “social media”, etc.), creates a community of practice (Wenger \& Snyder, 2000) in which learners interact with the teacher and among themselves. Mejias (2005) observed that "social software can positively impact pedagogy by inculcating a desire to reconnect to the world as whole, not just the social part that exists online” (p. 1). Dron (2007) argued that "social software... is [where] control and structure can arise through the process of communication, not as a result of design, but as an emergent feature of group interaction” (p. 233). Levy (1997) emphasized the importance to understand the relationship between theory and application of CALL, and Carol (1998) suggested that there must be complementary relationship between foreign language learning research and CALL practice to create a successful language learning environment.

White and Arndt (1996) argued that writing is a thinking process that demands conscious intellectual effort, which usually has to be sustained over a considerable period of time, and as a form of problem solving, it involves diverse processes. Peer editing, a useful method for language learning classroom, can serve as "a bridge between the writing process and collaborative learning” (Díaz, 2010, p. 97). According to Mawlawi Diab (2010), peer-editing can better motivate learners, so teachers should be encouraged to use peer-editing in the writing classroom. Bijami, Kashef, and Nejad's (2013) literature review on advantages and disadvantages of peer feedback recommends that even though there are some potential disadvantages, peer feedback (peer editing) can provide a flexible platform for the development of students' writing proficiency in a language learning class.

\section{Action Research}

There are different definitions and interpretations of action research (Crookes, 1993), but generally speaking, action research involves inquiring into the researcher's own practice through a process that normally includes entering a cycle of planning, acting, observing, and reflecting on an issue or problem with the aim to improve practice (Farrell, 2008).

Chamot, Barnhardt, and Dirstine (1998) suggested that foreign language teachers should have a good understanding of their students' learning process by observing the students' behavior, and analyze the behaviors to identify potential problems, then modify their teaching practices, and after the actions, evaluate the results. They provide a step-by-step guideline including (1) choosing a research question, (2) deciding what information 
is needed and how to collect it, (3) analyzing the data, (4) organizing and writing up the research results, and (5) incorporating research results into classroom practice.

Research literature demonstrates a close relationship among ICT, action research, and foreign language teaching. For example, Baralt, Pennestri, and Selvandin (2011) reported how they used Wordle, a data visualization tool, in an action research project that was designed to facilitate the teaching of foreign language writing within a dual coding theoretical framework. Khampusaen (2010) reported on an action research project that was conducted to examine how teachers of foreign languages in a Thai university were engaged with a professional development using ICT, and Zhang (2010) reported how an online environment was used for action research.

\section{Recommendations}

Due to the diverse academic backgrounds and career aspirations of students, it can be assumed that students' motivation for College English could be very different, and because of the learning needs and learning styles, it is impossible to have a "one fits all” classroom. Therefore, teachers may need to employ various strategies to learn about their students and students' needs as a starting point, and design and modify course content and teaching methods so as to motivate the students, enrich the learning environment, and enhance student learning.

In terms of CALL, it has been recognized by Chinese educators as a useful enhancer in foreign language teaching and learning (Gu, Hall, \& Hall, 2006; Yang, 2010). Especially in recent years, with the increasing availability and accessibility of ICT, students can access the Internet from school, home, or Internet cafes that are widely available in their communities (CINIC, 2014). It is believed that there is a great potential for teachers of College English to take advantage of ICT in their classroom. There may be arguments that many tools that are often mentioned in relevant literature, such as Facebook, YouTube, twitter, etc. are not readily available to users in China, but as it is widely aware, there are a variety of equivalents, such as QQ, youku, WeChat that are widely available and many students are using them for entertainment or social purposes. Teachers can use available technologies in College English classrooms as a motivator and enhancer (Zhang \& Xue, in press).

Education administrators have the responsibility to provide College English teachers with professional development opportunities to help update and upgrade their pedagogical knowledge and skills. What is equally or more important is that teachers need to keep in mind that a teaching career is a life-long learning process as course content, students, and teaching contexts constantly change in one way or another. It is highly necessary for a College English teacher (like teachers of other subjects) to keep doing action research so as to continuously improve their practice.

\section{Conclusion}

As a required subject in Chinese higher education curriculum, College English is deemed as an important component of the program of study for students at the tertiary level, and teachers of this subject face challenges regarding student motivation, learning outcomes, and teaching methods. This paper reviews literature related to motivation, CALL, and action research, which were chosen in this paper as three aspects for College English teachers in China. It is the authors' understanding that motivation for learning is closely related to learning outcomes of students, and with the increased affordability and availability of varies types ICT, it is beneficial for foreign language teachers to take advantage of ICT in the technology-rich teaching and learning 
environment to enhance learning. With the on-going change of student dynamics and educational environment, it is no doubt necessary for teachers to keep making efforts to improve their practice, and action research is one of the valuable ways for both researchers and practitionners in the education field to continuously carry out. The recommendations that are offered in this paper are for teachers of College English to consider in their design and delivery of the course. It is the hope of the authors that this paper can be a useful reference for teachers of other subjects and contexts as well.

\section{References}

Baralt, M., Pennestri, S., \& Selvandin, M. (2011). Action research: Using wordles to teach foreign language writing. Language Learning \& Technology, 15(2), 12-22.

Bijami, M., Kashef, S. H., \& Nejad, M. S. (2013). Peer feedback in learning English writing: Advantages and disadvantages. Journal of Studies in Education, 3(4), 91-97.

Brophy, J. E. (1987). Synthesis of research on strategies for motivating students to learn. Educational Leadership, 44, 40-48.

Carol, A. C. (1998). Multimedia call: Lessons to be learned from research on Instructed SLA. Language Learning and Technology, 2(1), 22-34.

Chamot, A. U., Barnhardt, S., \& Dirstine, S. (1998). Conducting action research in the foreign language classroom. Paper presented at the Northeast Conference: Conducting Action Research, New York.

China Internet Network Information Center (CINIC). (2014). The 32nd statistical survey report on Internet development in China. Retrieved from http://download.sina.com.cn/2013/ pdf/32.pdf

Crookes, G. (1993). Action research for second language teachers: Going beyond teacher research. Applied Linguistics, 14(2), 130-144.

Díaz, N. M. (2010). Peer editing: A strategic source in EFL students’ writing process. Colombian Applied Linguistics Journal, 12, 85-98.

Dörnyei, Z. (1994). Motivation and motivating in the foreign language classroom. Modern Language Journal, 79, 515-523.

Dron, J. (2007). Control and constraint in e-learning: Choosing when to choose. Hershey, PA: Information Science Publishing.

Farrell, T. S. C. (2008). Reflective language teaching: From research to practice. London: Continuum Press.

Gardner, R. C., \& MacIntyre, P. D. (1991). An instrumental motivation in language study: Who says it isn't effective? Studies in Second Language Acquisition, 13(1), 57-72.

Gardner, R. C., Smythe, P. C., Clément, R., \& Gliksman, L. (1976). Second language acquisition: A social psychological interpretation. The Canadian Modern Language Review, 32, 198-213.

Gu, Y., Hall, C., \& Hall, E. (2006). Using the computer in ELT: Technology, theory and practice. Beijing: Foreign Language Teaching and Research Press.

Hoven, D. (1999). A Model for reading and viewing comprehension in multimedia environments. Language Learning and Technology, 3(1), 88-103.

Hubbard, P. (2014). An invitation to CALL: Foundations of computer-assisted language learning. Retrieved from http://web. stanford.edu/ efs/callcourse2/CALL1.htm

Iyengar, S. S., \& Lepper, M. R. (1999). Rethinking the value of choice: A cultural perspective on intrinsic motivation. Journal of Personality and Social Psychology, 76, 349-366.

Khampusaen, D. (2010, September). Using an action research to investigate professional development: Improving the use of ICT in higher education. Paper presented at the 8th World Congress of Participatory Action Research and Action Learning, Melbourne, Australia.

Kim, I. (2005). Teaching English cross-communication styles through Internet-based instruction. PacCALL Journal, 1(1), 165-181. Krashen, S. (2007). Free voluntary web surfing. The International Journal of Foreign Language Teaching, 3(1), 2-9.

Levy, M. (1997). Computer-assisted language learning: Context and conceptualization. New York, NY: Oxford University Press. Littlewood, W. (1999). Defining and developing autonomy in East Asian contexts. Applied Linguistics, 20(1), 71-94.

Mawlawi Diab, N. (2010). Effects of peer- versus self-editing on students' revision of language errors in revised drafts. System, 38, 85-95.

Meece, J. (1991). The classroom context and children's motivational goals. In M. Maehr \& P. Pintrich (Eds.), Advances in achievement motivation research (Vol. 7, pp. 261-286). Greenwich, CT: JAI Press. 
Mejias, U. (2005). A Nomad's guide to learning and social software. In The Knowledge Tree (7th ed.). Retrieved from http://knowledgetree.flexiblelearning.net.au/edition07/html/la_mejias.html

O’Leary, M. (1998). Review of technology-enhanced language learning. Language Learning and Technology, 1(2), 20-22.

Oxford, R., \& Shearin, J. (1994). Language learning motivation: Expanding the theoretical framework. The Modern Language Journal, 78(1), 12-28.

Peterson, M. (2005). Learning interaction in an avatar-based virtual environment: A preliminary study. PacCALL Journal, 1(1), 29-40.

Rosenholtz, S. J., \& Simpson, C. (1984). The formation of ability conceptions: Developmental trend or social construction? Review of Educational Research, 54, 31-63.

Vygotsky, L. S. (1978). Mind in society: The development of higher psychological processes. Cambridge, MA: Harvard University Press.

Wenger, E., \& Snyder, W. (2000). Communities of practice: The organizational frontier. Harvard Business Review, (January-February), 139-145.

White, R., \& Arndt, V. (1996). Process writing. London: Longman Group.

Yang, Y. (2010). Computer-assisted foreign language teaching: Theory and practice. Journal of Language Teaching and Research, 1(6), 909-912.

Zhang, Z. (2010). Using online action research to improve a teacher education course. Ontario Action Researcher, 11(1). Retrieved from http://oar.nipissingu.ca/PDFS/V1112.pdf

Zhang, Z., \& Xue, Y. (in press). An investigation of how Chinese university students use social software for learning purposes. Procedia. 